Bronchial asthma

ciliary dyskinesia

cystic fibrosis protein genetic disease isoelectric focusing rabbit tracheal epithelium

\title{
Studies on Cystic Fibrosis Using Isoelectric Focusing. III. Correlation between Cystic Fibrosis Protein and Ciliary Dyskinesia Activity in Serum Shown by a Modified Rabbit Tracheal Bioassay
}

\author{
GREGORY B. WILSON, ${ }^{(32)}$ MELVIN T. MONSHER, AND H. HUGH FUDENBERG \\ Department of Basic and Clinical Immunology and Microbiology, Medical University of South Carolina,
} Charleston, South Carolina. USA

\begin{abstract}
Summary
We have developed a modified rabbit tracheal bioassay for use in investigating a possible correlation between cystic fibrosis protein (CFP) and ciliary dyskinesia factor (CDF) in human serum. The bioassay requires high standards of tissue selection, and all epithelial tissue must be free of underlying connective tissue. When serum samples were collected and processed carefully and warmed to $37^{\circ}$ before assay, CDF could be reliably detected in 31 of 31 sera from cystic fibrosis (CF) homozygotes or obligate heterozygotes in $35 \mathrm{~min}$ or less without prior fractionation or concentration of sera, whereas 13 of 14 normal control sera were nonreactive. $\mathrm{CDF}$-positive serum reacts in three consecutive phases: $(I)$ initial increase in ciliary beat frequency, (2) ciliary dyskinesia, and (3) tissue destruction with extrusion of single ciliated cells, mucus, and debris. Our results confirm the association of $C D F$ with cystic fibrosis. The bioassay is not specific for $\mathrm{CF}$, however, when whole sera are bioassayed, since serum from several patients with bronchial asthma also caused ciliary dyskinesia. However, this finding need not preclude using rabbit tracheal ciliated epithelial tissue as an assay for following the purification of CDF.
\end{abstract}

Isoelectric focusing showed that the presence or absence of CFP corresponded with that of dyskinesia activity in all sera tested except for the active samples from seven asthma patients, which were negative for CFP. The results indicate that CFP and CDF may be identical or closely related markers for the CF gene, and suggest that the activity detected by the rabbit tracheal bioassay in sera from patients with asthma and other diseases probably is caused by a substance different from a CF. specific CDF.

\section{Speculation}

Several substances in human serum can produce ciliary dyskinesia in rabbit tracheal epithelium, but only one appears to be a specific marker for CF. We speculate that CFP is related structurally or metabolically to a CF-specific CDF and that patients with bronchial asthma and other respiratory and autoimmune disorders harbor a substance that can produce ciliary dyskinesia but that differs from CF-specific CDF. 


\section{INTRODUCTION}

Spock et al. $(15,16)$ first described a materlal, termed "ciliary dyskíneS1a factor" (CDF). that was present in sera from cystic fibrosis (CF) patients (CF homozygotes) and their parents (obligate heterozygote carriers for CF) and disrupted the normal beating pattern of rabbit tracheal cilla. They consider-
ed cillary dyskinesla activity (CDA) to be a specific marker for the CF gene. ed cillary dyskinesia activity (CDA) to be a specific marker for the CF gene, bulinemia, bronchial asthma, bronchiectasis, cellac syndrome, hay fever) did bulinemia, bronchial asthma, bronchiectasis, cellac syndrome, hay fever) did
not cause riliary dyskinesia (15). Their findings were questioned for several not cause clliary dyskinesis (15). Their findings were questioned for several $\mathrm{CDF}$ could not be reproduced by several other investigators $(4,7,13)$.

The association of a CDF with cystic fibrusis has recently been conftrmed by Conover et, al. (8). However, their results Indicate that CDA is not a spefrom at tents with orher diseases produced a flliary dyskinesiasay, since ser tinguishable from that caused by sera from CF homozygotes ( 9 ). More recent doubt about the existence of a CDF has been ralsed by the high-speed cinemicrographic. studies performed by Cheung and .Jahn $(5,6)$. These investigators clalm that sera from homozygotes and heterozygotes for $C F$ does not cause dyskinesia of rabbit tracheal cllia. Instead, they maintain that cytolysis with cellular destruction of the clliated epithelfum is the major effect of serum,
and that destruction of the membrane leads to ciliostasis as a secondary ef-
fect (6).

We have previously described a protein assoctated with the CF gene, designated "cystic fibrosis proteln" (CFP). The CFP can be detected by isoelec tric focusing in sera from CF homozygotes and obligate heterozygotes (22) and appears to be a specif $1 C$ marker for CF $(20,22)$. In conjunction with another
proteln marker (bands $B, C, D$. CFP can be used to distinguish most homozypotes protein marker (bands $B, C, D$ ). CFP can be used to distingulsh most homozygotes or heterozygotes for CF from normal unaf fected individuals, and most heterozy-
gotes for CF from CF patients (22). It is not clear whether CFP possesses any gotes for CF from CF patients (22). It is not clear whether CFP possesses any
blological (e.g., enzymatic) activity, and its the possible role in the patho-
physology blological (e.g. enzymatic)
phys lology of CF is unknown.

Accordingly, we have developed a slightly modified verston of the rabbit In the present report, we describe our modified rabbit tracheal bioassay in detail; document photographically the sequence of events that follow the application of human serum to rabblt tracheal ciliated epfthelium; examine the spect. tients with bronchial asthma by bioassay and electrofocusing; and describe our initial at tempts to correlate CFP and CDF in thole serus. In another paper (26) our analyses of crude and partially purified perarations of CFP for CDA are reported and two methods are described for distinguishing the CDA in CF and asthmatic sera.

\section{MATERI ALS AND METHODS}

Collection and processing of samples. Serum was obtained from clotted blood of 16 CF patients (homozygotes), 15 obligate heterozygote carriers for CF, 7 siblings of CF patients, and 14 normal healthy controls. The blood was collected, processed, and frozen in allquots as described prevtously (22). Serum was also obtained from 7 individuals with bronchial asthma ("patient
controls") to compare the specificity of c1liary dyskinesia activity and CFP controls") to compare the specificity of clliary dyskinesia activity and CFP
as tarkers for detecting individuals homozyous or heterozygous for CF. All as tharkers for detecting individuals homozgous or heterozygous for CF. All
of the asthmatic patients were of $f$ any form of medication for at least 7 days prior to providing a blood sample. Informed consent was obtained from each
subject (or in the case of minors from their parents) before blood was drawn.

All normal healthy controls and "patient controls" had no known clinical or famlly history indicative of cystic fibrosis. Diagnosis of CF was confirmed in all CF patients by their clinical history and by the presence of an elevated concentration of chloride in the sweat (14). All siblings of CF patients had sweat chloride concentrations within the normal range. The age, shown in Table 1. Serum samp (IgG) levels of the subjects studied are selected to encompass a wide range of age and serum $\mathrm{IgG}$ levels, in order to
ellminate possible bias in the results.

Isoelectric focusing. Serum samples were analyzed for CFP by electrofocusing in a pH 5-10 gradient as described previously (22). Additional details of and precautions concerning the technique, sample collection and processing have also been reported (19). Samples were also screened for protein bands, $B, C$, and $D$ the markers that can be used to distinguish most $C F$ homozygote from heterozygotes (21,22). Since preliminary experiments indicated that bands, $B, C$, and $D$ have been omitted except where specifically, data for bands, $B, C$, and $D$ have been omitted except where specifically relevant to analyzed by laoelectric focusing, 1dentical aliquots of serum were tested for described below.

Med1a. Incomplete medium (M199-I) consisted of medium $199(\mathrm{pH} 7.2)$, contalning Earles salts (Grand Island Blological Co., N.Y.), sodium bicarbonate $(2.2 \mathrm{~g} / 11$ ter) and $2 \mathrm{mM} L-8$ lutamine, supplemented with penic111in (50 un $1 \mathrm{ts} / \mathrm{ml}$ ) and $\mathrm{streptomycin}(50 \mathrm{mcg} / \mathrm{ml})$. Complete culture medium (Ml99-C) consisted of 902 M199-I, plus $10 z$ fetal calf serum (Grand Island Biologica Co., N.Y.)

(5-7 Culture of tracheal tissue. Normal female New Zealand white rabbits were removed under used exclusively. The rabbits were killed and the tracheas The tracheal tissue was washed twice in a $60 \times 15$ by Conover et al. (8). petri dish containing $10 \mathrm{ml}$ of $M 199-\mathrm{I}$ at $37^{\circ} \mathrm{C}$ to remove excess blood, and the epithellum was removed with a scalpel as described previously (8), except that M199-1 was used $(15,16)$. The epithelial sheets were transferred to ste ile Falcon tissue culture petri dishes contalning approximately $2-3 \mathrm{ml}$ of
Ml99-I at $370 \mathrm{C}$, and cut into small pleces (roughly $5 \mathrm{~mm}$ square) with a scalpel. M199-I at $37^{\circ} \mathrm{C}$, and cut 1 nto small pleces (roughly $5 \mathrm{~mm}$ square) with a scalpel
Ten to fifteen pieces were transferred to a sterile $60 \times 15 \mathrm{~mm}$ tissue culture Ten to fifteen pieces were transferred to a sterile $60 \times 15$ mo tissue culture
dish containing $3-4 \mathrm{ml}$ of $M 199-C$ and placed in a humidifled issue culture incubator at $37^{\circ} \mathrm{C}$ and at $5 \% \mathrm{CO}_{2}$ tension unt 11 used for bioassay 24 to $48 \mathrm{~h}$ later. A pH of 7.2 to 7.4 was maintalned throughout the culture.

Bloassay. Explants were quickly examined in the tissue culture dish by

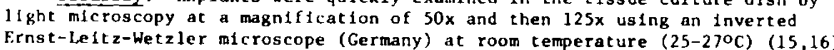

The criteria for selecting tissue used in bioassay generally folluwed those set forth by Conover et al. (8): (a) Only those pleces with vigorously active cilla, minimal out growth, and unobscured burders are used. (b) The clliated borders must be synchronously beating, uniform, and free of mucous contamina-
tion. (c) The pH of the culture must be between 7.0 and 7.4 .

In addition, it is Important that the tissue specimen used be totally free of any underlying connective tissue. Connective tissue under an othermicroscopy at a magnification of 50-125x. Figures $1 \mathrm{~A}$ and $1 \mathrm{~B}$ show photographs of two separate of two separate pieces of tracheal epithellum which mect these conditions, except that the sample shown in Figure $1 B$ contains some underlying connective issue. Both pleces of tissue have an active, syncrhonously beat ing cilliated
border free of mucus (Figs. IC and ID). In preliminary experiments we found that epithelial tissue with underlying connective tissue showed a cillary dyskinesia reaction in response to normal control serum similar to that caused dyskinesia reaction in response to nurmal control serum similar to that caused
by $C F$ serum samples. Identical aliquots of the same normal control sera fall-
ed to cause a reaction in tissue specimens devold of underlying connective tissue. Also, addition of connective tissue to previously nonreactive normal sera causes conversion of the sera to a positive status and wlll produce a dyskinesia reaction in tissue devoid of connective tissue (18). The connective Issue apparently activates a compone
specific ciliary dyskinesia reaction.

Samples that met the above criteria were removed as required for bloassay with a wooden applicator stick, transferred to a glass slide, washed with M199-I at $37^{\circ} \mathrm{C}$ to remove old M199-C, and covered with a solution containing
2 drops of fresh M199-I at $370^{\circ} \mathrm{C}$ and 2 drops of serum to be tested. The serum was thawed and warmed to $37^{\circ} \mathrm{C}$ just prior to the assay. Prewarming the sample to $37^{\circ} \mathrm{C}$ just prior to bioassay serves two purposes (18). (A) When one compare the results obtained by Spock et al. $(15,16)$ and Conover et a1. (8) for the tIme of onset of clliary dyskinesis it is obvious that the kinetics of the
reaction 1 ike may biological reactions is temperature dependent. To achieve reaction like may biological reactions is tempersture dependent. To achieve a time interval for the assay that is condusive for using the system to follow the purification of various CDA's, we found that starting the reaction at $37^{\circ} \mathrm{C}$
(both the tissue, medium, and sera are at $37^{\circ} \mathrm{C}$ ) allowed for completion of the (both the tissue, medium, and sera are at $37^{\circ} \mathrm{C}$ ) allowed for completion of the
test by $35 \mathrm{~min}$ ( 35 of 42 samples react by $30 \mathrm{~min}$, see Results) and did not necessitate using a $37^{\circ} \mathrm{C}$ warm room or a temperature regulated microscope stage. prefer not would work in a $37^{\circ} \mathrm{C}$ warm roo hented microscope stage and/or would prefer not to work $1 \mathrm{n}$ a $37^{\circ} \mathrm{C}$ warm room, therefore,
the present alternative procedure was worked out. (B) In addition, preheating the present alternative procedure was worked out. (B) In addition, preheat
prevents tramatization of the tissue which $1 \mathrm{~s}$ already at $37^{\circ} \mathrm{C}$ for reasons mentioned above.

A cover slip was placed over the sample, and the assay was monitored at room temperature using a magnification of $400 x$ and phase-contrast 11 umination (15,16). An appropriate border of cllia was localized within $60 \mathrm{sec}$ af ter tinuously for the first $30 \mathrm{~min}$ and then at $5-\mathrm{min}$ intervals for an additional $30 \mathrm{~min}$. Each serum specimen was assayed at least twice by an investigator who was unaware of the source of the samples. Duplicate readings usually did not vary by more than $10 x$. When two assays for a single sample did not agree, the sample was retested in the same manner unt 11 consistent results were ob-
talned. Cillary dyskinesia, not cessation of the c1liary beat was used as the sole criterium for a positive reaction (see Results).

With each bioassay, normal control serum (shown by electrofocusing to be CFP negative) was tested initially to evaluate the vitality of the tissue. In addition, a control sample of normal, nonreact lve serum was assayed simultaneously with several of the unknown serum samples tested. Two microscopes
were used, so that any changes in clliary beating caused by application of the were used, so that any changes in clliary beat ing caused by appld
unknown sample could immedlately be compared with the control.

Photom1crography. Photomicrography was performed with a 35-mm Minolta

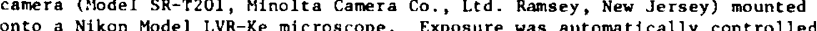
with a Nikon Microflex (Model AFM), and Kodax Tri-X ASA $400 \mathrm{film}$ was used.

\section{RESULTS}

Ciliary dyskinesia activity and cystic fibrosis protein in whole human serum. The results of screening whole human sera for cillary dyskinesia
activity (CDA) are shown in Figure 2. All sera from 16 CF homozygotes and obligate heterozygotes produced clliary dyskines in 35 min orygotes and 15 from $C F$ homozygotes tended to cause cillary dyskinesia to occur in less time than those sera from obligate heterozygotes ( $14 \pm 8$ and $25 \pm 8$ min respect ively
(mean + S.D. )). The re was extensive overlap, however, between values for the (mean \pm S.D.)). There was extensive overlap, however, between values for the
two groups, making it impossible to distinguish bewteen homozygotes and heterotwo groups, making it impossible to distinguish bewteen homozygotes and hetero-
zygotes on an individual basis.

Sera from 13 of 14 normal control individuals and 3 of 7 siblings of CF patients did not cause clliary dyskinesia by the end of the assay period ( 60 $\mathrm{min}$ ) and were therefore considered negative for the cillary dyskinesia factor (CDF) (Fig. 2). Sera that falled to react by 60 min were negative for longer
periods, but for practical purposes observations were generally discontinued periods, but
after $60 \mathrm{~min}$.

No correlation was found between the age or sex of the subjects tested and the reactivity of their sera. No attempt was made to correlate severity of the disease in the CF patients tested with the time required ror ciliary dysk1nesla to occur, since all obligate heterozygote carriers for CF, and 4 of
siblings of CF patients that were positive on bioassay(Fig. 2) were totally asymptomatic.

When the serum samples were assayed for CFP by isoelectric focusing (Fig. 2), all those positive for CDA were also found to be positive for CFP. Thre of four siblings of CF patients were positive for CFP and CDA, but lacked elther band $B$. C. or D, indicating that they were heterozygote carriers for CF. Cne normal control and one sibling positive for CFP and CDA did not lack band B, C, or D. (In previous studies, approximately 25z of the obligate heterozygote carriers analyzed were positive for all three bands.) Sera from patient controls (bronchial asthma) were found to elicit a ciliary dyskinesia
reaction fdentical to that produced by sera from individuals homozyous or reaction Identical to that produced by sera from individuals homozygous or heterozygous for $\mathrm{CF}$ except that several sera from asthmat ic pat lents also produced subsequent cillostasis. However, none of the patient controls were
positive for CFP and all were positive for bands B, C, and D, excluding the positive for CFP and all were positive for bands B. C, and D, excluding the
possibility that they might be carriers of the CF gene (Fig. 2).

Documentation of ciliary dyskinesla and membrane destruction. When sera 
the folluwing siequence of events wils ubserved: (a) The first noticeable - f feet wits an increase in the ciliary heat trequency. The cilla continued to beat sinchronously, but the beat was faster than that of the normal controls. run simultaneousily or of the same preparation at the beginning of the assay. (b) The ciliary beat became disorganized. Cillary asynchrony or dyskines normal control photographed at the same time (Fig. $4 \mathrm{~B}$ and $4 \mathrm{C}$ ) and also from the same preparation at the $t$ tme of applteation of the sierum sample. (Fig. 3A). same preparation at the time of applfcation of the serum salnple (Fig. 3A).
This change ln the appearance of the ciliary beat (e.g. illiary dyskinesia) was the onlv criterion used to characterize a sample as heing CDA-positive. wias the onlverfterion used to characterize a sample as heing and-positive. of the tissue usially wecurred. The burder became abscure, single cells, muc and debris were extruded from the tissue (Fig. 3D), and many but not all of the cilfa ceased to beat. In contrist, the normal cont rul preparat on con(a to i) was observed dasily, whthout special optical equipment (set Material and Methods)

Not all CDA-positive sera (Fig. 2) caused destruction of the eptthelial tissue by the end of the assav period (60 min). Altheugh clllary dyskinesia was the only criterion used to characterlze a positive reaction, 3 of 16 ( $F$ homozygote sera and 2 of 15 obligate heterozygote sera were also cilfotoxic

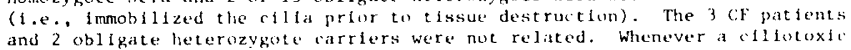

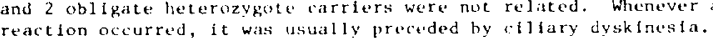

\section{DISCUISSION}

This investigation was destgned to estithlish a reliable and reproducible

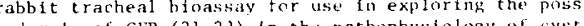
and role of C.FP (21,22) in the pathophystolngy of cost fl fibrosis. We chu hecause the latter is subfect to seasonal and reglonal vartations in the acossslbility of rassostrea virginica, the aysiter
(11), whereas rabbits are readily accessible.

The rahbit tracheal bloassay described in this report $1 \mathrm{~s}$ a modificatton of the bloassays described hy Spock et al. $(15,16)$ and conover et al. (8). Tissue was selected according to the criterta of conover et al and the thons: (a) tissue the proticol of Spock et al. With the following modiflicitissue culture petri dishes were used rather than Falcon culture flasks; in (c) the medium (Medium 199) was supplemeded with $10 \%$ fetal calf serum rather than $20 \%$ rabbit serum. In additfon to the requirements for tissue selection proposed by conover et al. (8), we have found that the rabhit traciseal epithe1 lum must be free of any connectlve tlssue. Inless this requirement is met, the rabbit tracheal bioassay is totally unreliable, fn that normal sera invarlably produce cillary dyskinesia identfcal to that produced by sera from $\mathrm{CF}$ homozygotes or heterozygotes. Additional research is required to determin whether the material In normal serum apparently activated by the presence of connective tissue is identical to the CDF found in serum from homozygotes or heterozygotes for CF. Nonetheless, our finding might explaln the results ", other investigators who found CDA in sera from normals as well as CF homozy-
gotes $(4,7,13)$, espectally those of Cherry et $a 1$. (4), who used whole tractheal gotes $(4,7,13)$, especially those of Cherry et al 14 ,
ring explants rather than just the clliated epithelium.

Our modifled bloassay can detect clliary dyskine'sta activity in serum from homozygotes or heterozygotes for $\mathrm{CF}$ without prior tsolation or concentration of the euplobulin fraction $(15,16)$. The hioassay requires more time than that of Conover et. al. (8) but does not have to be performed In a 37 . high quality, and careful processing and storage of the serum samples prior to bioassay collectively increase the sensitivity of the assay suf ilcienty
to permit detection of a CDA in serum from heterozygote carrters as well as from $C F$ homazygotes.

Both in our assay (22) and in that of Conover et a1. (8), the blood is

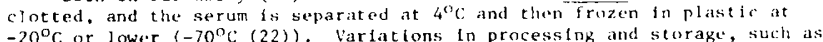
clotting at room temperature or $37^{\circ} \mathrm{C}$, in processing and storage, such is freezing and thawing, may cause $10 \mathrm{~s}$ s of (F-specific activlty and/or Increased nonspecific activity (18). Dur findings may explain in part the problems encountered by other investigators $(4,6,7,13)$ in detection of a $\mathrm{CDF}$. That erroneous results can result from improper processing and stira
samples is also evident from the report of Bowtnan $: t$ al. (3).

Recently, Cheung, and lahn (6) teported that serum from homozygntes or heterozygotes for CF, or even from normal controls, did not cause cillary dyskinesta, and that cytolysis was the major effect of human serum on rab tracheal explants, with cillostasis as a secondary effect following total
destruction of the epithelial membrane. In contrast to the work of cheung destruct ion of the epithelial membrane. In contrast to the work of Cheing
and Jahn (6), the present studies demonstrate that ciliary dyskinesia is the and Jahn (6), the present studies demonstrate that ciliary dyskinesia is the
first effect produced by human serum on rabbit tracheal ipithellum; cytolysis f1rst effect produced by human serum on rabblt tracheal epithellum; cytolysis
and/or obvious destruction of the 11 ssue follow much later. Cillary dyskinesi and/or obvious destruction of the tissue follow much later. Cillary dyskines
can be distinguished easily from normal synchronously heating cllia without can be distinguished easily from normal synchronously heating cllia without
the aid of special optical equipment ( 1 . . an ordinary microscope can be used) and can be documented photographtcally without the ald of high-s

Disparity between the results of Cheung and Jahn and others $(4,6,7,13)$

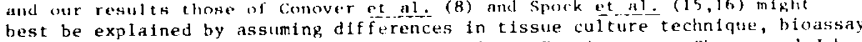
or processing and storage of the serum samples. For instance, Cheung and Jahn $(5,6)$ did not culture the rabbit tracheal epithelfum prior to bfoassay, the t1ssue was not free of debris (see Fig. 4 in Ref. 5), and sume of the sera used for bloassay were not processed at $4^{\circ} \mathrm{C}$ and/or were not stored at tempera tures below $-20^{\circ} \mathrm{C}(17)$.

Although our results agree with those of Spock et al. $(15,16)$ and Conover et al. (8) in that sera from individuals homozygous or heterozygous for $\mathrm{CF}$ caused cillary dyskinesis whereas sera from normal healthy controls did no (the one normal healthy control positive for CDA might he expected from a heterozygote carrier frequency of 1 in 20 in the Caucasian population (12))
we do not agree with the finding of Spork rt al. $(15,16)$ concerntng the we do not agree with the finding of Spork at al. $(15,16)$ concerning the
sperificity of the CDA in whole serum as a marker for the CF gene. As nur sperificity of the CDA in whole serum as a marker for the CF gene. As nur
results show (Fig. 2), 7 of 7 samples from patients with bronchial asthma results show (Fig. 2), 7 of 7 samples from patients with bronchial asthat
produced c1liary dyskinesta nearly identical to that caused by sera from CF produced clliary dyskinesta nearly identical to that caused by sera from
homozygotes. This finding conf 1 rms the results of conover et at. ( $(9)$, which indicated that sera from patlents with a vartety of respiratory and autoimmun produced hy cF sera. We strongly feel, hewever, that the substance in serat from patients with bronchial asthma is not ident ical to the cillf found in serta tected by electrofocusing.

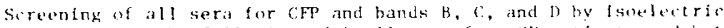
focusing fadicated the following: (a) all sera from (if pat lents and helerwzy gotes for CF were found to contaln CFP; (b) serm from CDF-positive siblins of CF pat lents and serum from the normal control that was (DF positive also contained (Ff': (c) normal samples that were cif-negative were nonreactive th the rabbit tralleat hioassay; and (d) as in cur previuus stody (22), tiksst

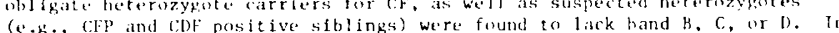

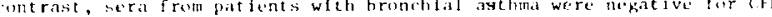
In addition, whes isthmitic sera are fractionated by sephadex (i-200 get illeration or DFAE-cellulose chromatography (26), the cillary dysklnesid. activity elutes in a different fraction from the CDF activity in CF sera. The CF-CDA is found in the same tractions at chp.

The finding that all crp-pesiclve sera produce dilary dvskinesia sugpest

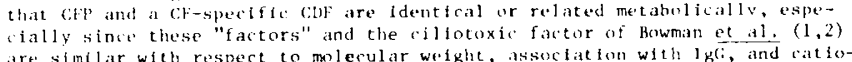
are similar with respert to molecular weighe, assocfat fon with lghe, and rat
hic charge $(1,2,10,21,23)$. No definte conclusions can he drawn, however, from studies using only whole serum. Separat ion of CFP, CF-specifte CDF, and

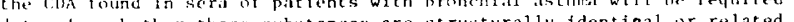
determine whether these substances are structuraly tentical or related
metabolially. Gur findings concerning their purification and activity are reported in incther paper (26).

\section{ت̈U.iLLLiuli}

A modified rabbit tracheal bioassay for cystio fibrosts (CF) diliary dyskinesiat factor (CDF) has been perfected in this laboritory to explore possible hiologlcal activity arid role of cystic fibrosis protein (CFP) detected by electrofocusing in the pathophysiology of CP. Ciliary dyskines (F) without isolation or concentration of the euglubulin fraction. Serit from is dyskinesla. Dur results confirm the existence of a CDF in sera from homozy gotes and heterozygotes for $\mathrm{CF}$ but indicate that diliary dysklfiesia activity is not specific for CF when whole serum is assayed.

The effeet of CDF-posteive sera on cilfated rabbit tracheal epithelium was documented photographlatcally and found to consist of three consecut dve (b) cillary dyskinesta, followed $10-40 \mathrm{~min}$ later hy (c) destruction of the tissue with extrusion of single ciliated cells, mucus, and debris.

Elent rofocusing of the same sera tested for CDA Indicated complete concordance between CFP and CDA positivity in sera from CF homozygotes and oble kate heterozygotes, siblings of CF homozygotes, and normal
pat lents with hronchial asthma, however, were CFP negative.

It is pussible that several factors in human serum can cause ciliary dyskinesia, but that only one of these may be specifle for CF. Our results sugkest that CFP may he similar or related st ructurally or metabolically to a CF-specifte CDF; however, purification and compartson of CFP and the substances responsthle for CDA found in CF sera and in sera from patients wi definite cunclusions can be drawn.

\section{REFERENCES AND NOTES}

1. Barnett, D.R., Kurosky, A., Bowman, B.H., Hutchison, H.T., Schnoyer, I. and Carson, S.D.: Cystic Fibrosis: Molecular welght

2. Ciliary Inhibitor. Tex. Rep. B1ol. Med. 31:703 (1973). of the cystic ffbrosis ciliary inhibitor. In: J.A. Mangos and R.C. Talamo, Fundamental Problems in Cystlc Fibrosis and $\overline{R e l a t e d ~ D i s e a s e s . ~ p . ~} 29$

Bowman, B.H., Hirschhorn, K., and Bearn, A.G.: Bioassay of cystic flbrosis Bownan, B.H., Herschhorn, K.
factor. Lancet $1: 404$ (1974).

4. Cherry, J.D., Roden, V.J., Anthony, B.S., Rejent, J., and Dorner, R.W.: The inhibition of cillary activity in tracheal organ cultures by sera frum

5. Cheung, A.T.W., and Jahn, T.L.: HIgh speed c Inemicrographle studies an rabbit tracheal clliated epithella: Determinatic
tracheal cilla. Pediat. Res. 10:140 (1976).

Cheung, A.T.W., and Jahn, T.L. : High speed cinemlcrographic studies on rabblt tracheal (ciliated) epithelia: Cytolytic effect of cystic fibrosis serum on tracheal epithelial cells. Pediat. Res. 10:144 (1976).

7. Christensen, J. and Norrevang. A.: Studies on the effect of CF serum on fresh tissue form Drelssena glils, oyster gills and rabblt tracheal mucosa. In: D. Lawson: Proceedings of the fifth International Cystic Fibrosis Conference. P.49 (C.Nicholls and Co., Ltd., Great Britain, 1969).

8. Coniver, J.H., Bonforte, R.J., Hathaway, P., Pac Inc, S., Conod, E.J., Hirschborn, K., and Kopel, F. B.: Studles on clliary dyskinesta factor in

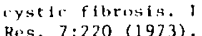

9. Conover, J.H., Conod, E.J., and H1rschtorn, K. : CHliary dyskinesia factor in immunological and pulmonary disease. lancet $1: 1194$ (1973).

10. Conover, J.H., Conod, E.J., and Hirschlorn, K. Studies on ciliary
dyskinesia factor in cystic fibrosis. IV. Its possible identification as dyskinesia factor In cystic flbrosis. IV. Its poss (1974).

11. Lockhart, L.H., and Bowman, B.H.: Assay for detection of the cystic fibrosis gene. Tex. Rep. Biol. Med. 31:631 (1973).

12. McCombs, M.L.:
$31: 615(1973)$.

13. Posselt, H.G., and Bender, S.: Heterozygote testing in cystic fibrosis: Experimental studies with cilia of the mussel Dreissena polymorpha $Z$. Kinderhe1lk 110:98 (1971).

14. Schwachman, M.E.: Cystic Fibrosis. In: E.L. Kendig. Disorders of the Respiratory Tract in Children, p. $5 \overline{41}$ (W.B. Saunders Co., Philadelphia, 1967).

15. Spock, A., Hefick, H.M.C., Cress, H., and Logan, W. : In vitro study of
ciliary motilfty to detect Individuals with active cystic fibrusis and carriers of the disease. Mod. Probl. Pedlat, 10:200 (1967) 
10. Spock, A., Helck, H.M.C., Cress, H., and Logan, W.S.: Abnormal serum factur in pattents with cystic fobrosis of the panc reas. Pediat. Kes.

17. WIIsin, (i., B.

18. Wils Angele's $(1972-73)$.

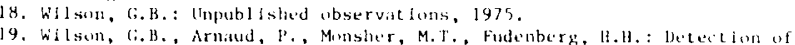

20. Cystic Fibrosis Protein by Electrofocusling. P'ediat. Re's. 10: (in press) (1976)

Warem, ..B., Burdash, ...., Armad, P., Monsher, ...., and Fidenberg, H. H. fibresis humozygotes and obllgate heterozgote carriers. Scind... Immuncl. (in press) $(1976)$.

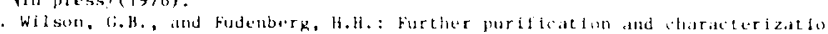
"If serum proténs used to detect eystic lobrosis genotypes by isoelectric focusing. Tex. Rep. Hiul. Med. 34: (in press) (1976).

22. Wilson, (i.H., Fudenberk. H.H., and Jihn T.Le: Studles on cysetic tibrusis ustak isoelectric tocusing. I. An astay for datection of ystic fitorosis bumozyotes and heterozygote carriers from serum. Pediat. Re's.9:635 (1975)

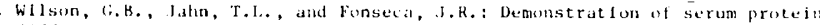
differences in costid fobrosis by iswedectric focusing in thin-layer polyacrylamide gels. Clin. Chim. Acta. 49:79 (1473).

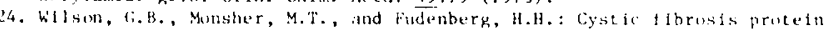

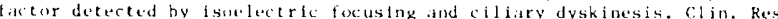
24:295 (1976).

5. Wilsun, (i.B., Monsher, M.T., and Fudenberg, H.H.: Purificatlen of eystic

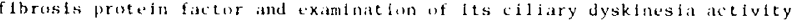

26. W1lcon, (i,B., Monsher, M.T., and Fudenberg, H.th. Studles on cystle fibrusi us lak isoelectric focusing. TV. Distlactun between clliary dyskinesta activity in eystic fibrosis (CF) and asthmatic serat and asser lation of CF protein with the decivity in cystio fibrosis serung. Pedtat. Res.,

The authors gratefully acknowledge the assistance of Normal lewiston. M.v. Margaret. Jenkins, M. D, and Joth Whaten, M.D., in wbtaining some of the of Charles L. Smich.

28. Mr. G. B. Wilson was a Postdectoral Research Fellow of the Cystic fibeosis Research Foundation during the early phases of this investigat lon.

29. The research was supported in part by USPHS (irants Bil)-09938 and Al-1 3484 and by the South Carolina State Appropriations for Research HRS24 and A705. This is publication no.61 from the Department of Basic and cilinical 1 mmunology and Microblology of the abstract form $(23,24)$

32. Requests for reprínts sheruld be addressied to: G.B. Wilson, Plt.n.,

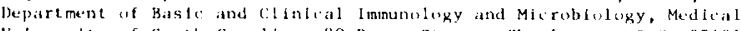
Unlverslty of South Carwlina, 80 Barre Street, Charleston, S.C. 2940 (USA).
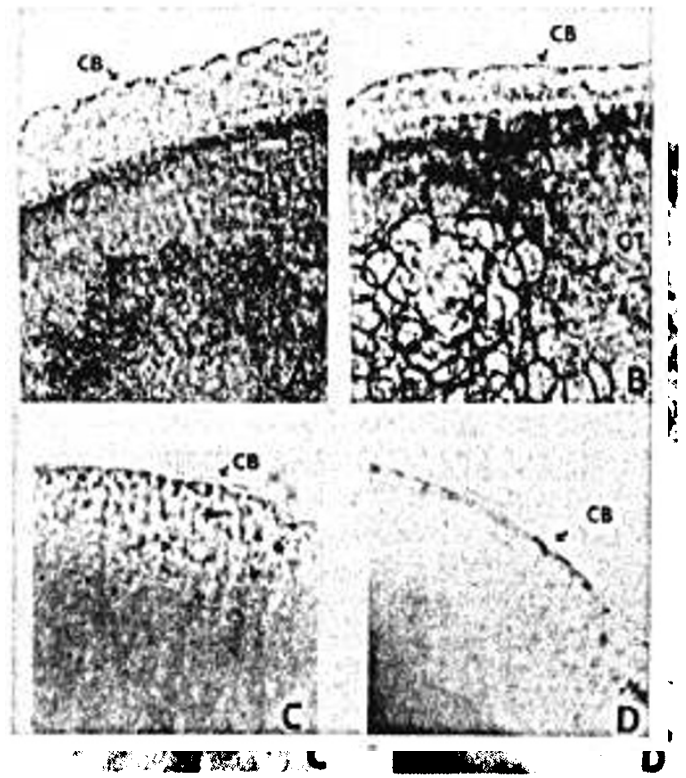

Fig. 1. Rabbit tracheal clliated eplthelium as observed under phase-cont rast microscopy. ( $A, B)$ Intact clliated burder (CB) free of mucus observed at a magnif teat fon of $100 x$. The tlssue In Flgure is shuws underlying connectlve

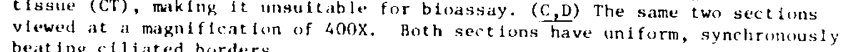

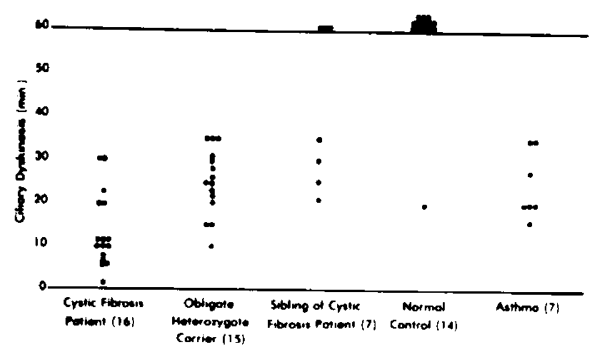

Fig. 2. Time required for production of dyskinesia of rabbit tracheal clith serum. Serum satmiles tadicated as taking $60 \mathrm{~min}$. or longer showed most tive and the end or the assay $(60 \mathrm{mln})$. Solld circles indicate sera as determined by iscelectric focusing (see Materials and Methods).

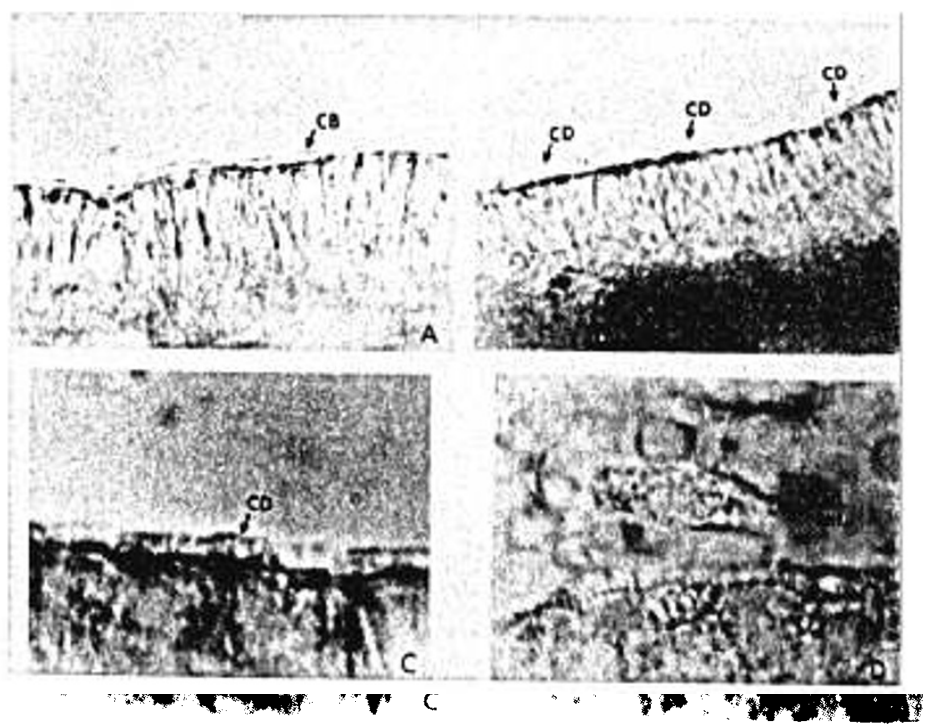

Fin. 3. Effect of alplication of sera positive for cystic fibrosis protedo and ciliary dyskinesia factor on rabuit tracheal cillated eptehelium as observed by phase-contrast microscopy. (A) Tissue just after applation of the sample ( $5 \mathrm{~min}$.). Note that the clltated border (CB) is free of mucus and

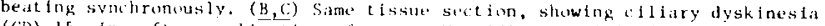
(ID) Is min. after application of serum. Magnification 400X (B) and $1000 \mathrm{X}$ (C). border ts 20 mith. after the miscet of cillary dyskinesis (1000X). The clliated of nucus, debris, and of single inlls (and ext.)
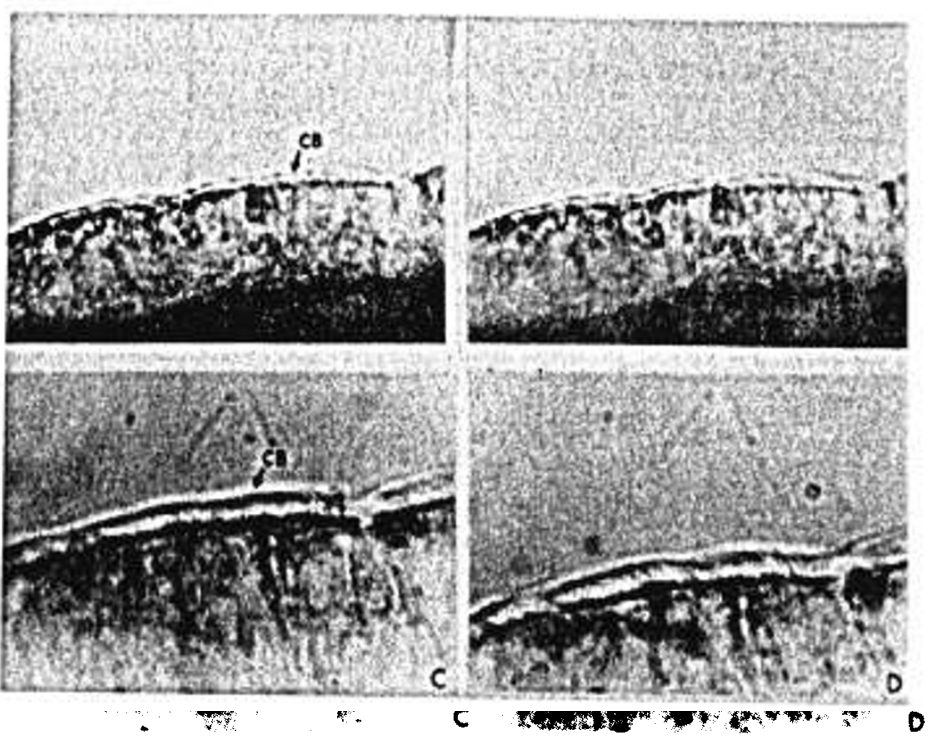
frablt tracheal ciliated epicheltum as ubserved by phase$15 \mathrm{~min}$ minscopy. (A) $5 \mathrm{~min}$. after applfeation of the sample (400X). (B, C) after applfeation of the sample ( $1000 \mathrm{x}$ ). Note that atter applacating of the sample (1000x). Note that the rilia continue to beas synithonously and there ts no expulston of macus ar debris ar extrusion of

TABI.E 1. Serum Igic Level, Age, and Sex of Subjects Analyzed fur cystio

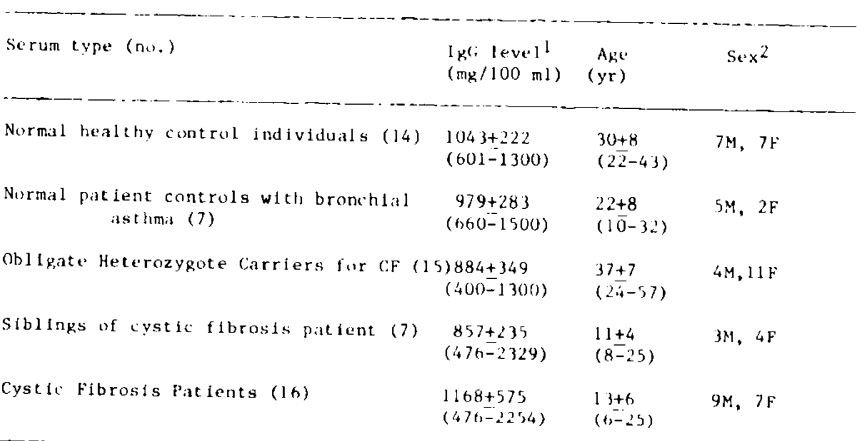

\footnotetext{
${ }^{1}$ Serum concentration uf lg(i dectermined by single radlal
immunodiffusion (ref. 22). Mean + S.D. and ritnge. ${ }^{2} M$, male; F, femalt.
} 